University of Rhode Island

DigitalCommons@URI

$9-2016$

\title{
Vested Interests, Venue Shopping, and Policy Stability: The Long Road to Improving Air Quality in Oregon's Willamette Valley
}

Aaron J. Ley

University of Rhode Island, ajley@uri.edu

Follow this and additional works at: https://digitalcommons.uri.edu/psc_facpubs

The University of Rhode Island Faculty have made this article openly available.

Please let us know how Open Access to this research benefits you.

This is a pre-publication author manuscript of the final, published article.

Terms of Use

This article is made available under the terms and conditions applicable towards Open Access

Policy Articles, as set forth in our Terms of Use.

Citation/Publisher Attribution

Ley, A. J. (2016), Vested Interests, Venue Shopping, and Policy Stability: The Long Road to Improving Air Quality in Oregon's Willamette Valley. Review of Policy Research, 33: 506-525. doi:10.1111/ropr.12190 Available at: http://dx.doi.org/10.1111/ropr.12190

This Article is brought to you for free and open access by the Political Science at DigitalCommons@URI. It has been accepted for inclusion in Political Science Faculty Publications by an authorized administrator of DigitalCommons@URI.For more information, please contact digitalcommons-group@uri.edu. 
Vested Interests, Venue Shopping, and Policy Stability:

The Long Road to Improving Air Quality in Oregon's Willamette Valley

\author{
Aaron J. Ley \\ Assistant Professor \\ Department of Political Science \\ University of Rhode Island \\ Kingston, RI 02881 \\ ajley@uri.edu
}

\begin{abstract}
A lot of scholarly attention has focused on why groups choose to pursue their policy goals in one venue over another. This manuscript adds to the literature by testing a new theory of venue shopping, the Adaptive Venue Shopping Framework. This manuscript finds empirical support that groups choose venues by strategically assessing the institutional context which involves three primary elements: the group's mix of resources, their opponent's resource strengths, and the degree of venue accessibility, which is a combination of opponents degree of control over a venue and a venue's image amiability or receptivity. In addition to confirming these findings, this case study links the literature on venue shopping with recent scholarship about "vested interests" by demonstrating how a powerful agricultural group came to dominate in a legislative venue, how it protected its policy victories from reversal, and how it kept policymaking from shifting into alternative venues, thus leading to long-term policy stability. Furthermore, it demonstrates how newly emerged groups can achieve policy success against stronger opponents by threatening to seek their policy goals in alternative institutions.
\end{abstract}




\section{Introduction}

If there is an uncontested political reality in American politics it is that multiple venues are available to groups seeking to dislodge the hard-fought policy successes of past political victors. When political actors are successful at protecting their policy victories from reversal, they produce the policy stability that has become such a well-known feature of American politics. This policy stability is an attribute of governance that receives less scholarly attention than traditional work focusing on the factors driving policy change. As Terry Moe (2015) puts it:

Change is rooted in stability, and any effort to build a productive theory of change must take full advantage of what the theory of stability already has to tell us...about the forces of resilience that protect the status quo (p. 283)

While it is critically important to understand the activities of reformers in producing policy change, it is equally important to "understand the vested interests that oppose them and that regularly weaken, distort, or sidetrack major change" (Moe 2015, p. 302). We quickly forget that today's "forces of resilience," were at one time yesterday's political newcomers who also agitated for policy change, at times seeking to shift policymaking into venues offering them the best opportunities for changing policy. What happens when we place "vested interests" at the center of our political analysis and what can we learn about the venue choices that these powerful groups made before coming to dominance? And, most importantly, how do these groups insulate their policy victories from reversal, thus creating the policy stability that is such an enduring feature of American politics?

There is no shortage of recent scholarship that examines the strategies of groups as they are choosing venues for pursuing their policy goals (e.g., Ley and 
Weber 2015; Buffardi, et al. 2015). This paper uses the first ever empirical case study of an environmental policy conflict in the Pacific Northwest, the problem of agricultural field burning in Oregon, to explore how an emergent, but later dominant, agricultural interest group chose among the various venues that were available to it. This analysis advances theory in the area of venue shopping by providing the first empirical test of the "Adaptive Venue Shopping (AVS) Framework," a synthetic venue shopping framework arguing that boundedly rational groups select venues by assessing the institutional context and adapting their strategies on the basis of learning what does and does not work.

If initial venue choices are important for winning policy victories, then insulating those policy victories from reversal becomes an important next step that is underexplored by scholars interested in the venue choices of groups. Along with finding support for the AVS Framework, this manuscript links the venue shopping literature with Moe's (2015) recent insights about policy stability by demonstrating how "vested interests" produce "institutional inertia." Institutional inertia, introduced here as a key source of gradual and incremental policymaking with path dependent characteristics, occurs when policy problems are thrust into specific policymaking venues and remain there even though newly emerged groups prefer venue changes. Interests can become "vested" and, thus, produce institutional inertia by developing strategies that provide organizational leaders with strong financial motivations to institute "blocking" strategies that keep policy from being acted upon or that keep policy from drifting into new and inhospitable venues. To demonstrate how industry groups successfully fend off efforts to change their 
practices, I use a case that involves a "focusing event" that should have produced significant policy change or, at the least, shifted the issue into new policymaking venues. That a focusing event of the magnitude described in this case failed to shift policymaking into new venues, or to advance meaningful policy change, demonstrates how organizations can manufacture strong motivations for its members to create the institutional inertia and long periods of policy stability, in this case lasting twenty years, that precede policy change.

In addition to examining the strategies undertaken by groups that seek to insulate their policy victories from reversal, this manuscript also examines the experiences of groups that emerge to successfully challenge tough cases of policy entrenchment. Even though well-established groups enjoy clear advantages after having spent years insulating their policy victories from reversal, newly emerged groups can level the playing field through their persistent efforts to shift venues or by simply threatening to shift policymaking into newer venues. The efforts in this case were made successful because a loosely coordinated coalition of interests acted together through a state legislative policy entrepreneur who credibly threatened to use legislation to resolve the longstanding policy problem through a state referendum.

Before presenting a case study of field burning politics in Oregon, this paper begins by describing the various theories that are used to understand the activity of venue shopping. This discussion of theory is followed by a section that describes the methods used to create an in-depth case study of field burning in Oregon, followed by a thick description of field burning politics in Oregon. 


\section{Theoretical Advancements in the Study of Venue Shopping and the AVS Framework}

Ever since E.E. Schattschneider (1963) wrote that groups pressing for policy change increase their chances of success by expanding the scope of political conflict, scholars began examining "why" and "how" groups chose policymaking venues for pursuing their policy goals. What emerged from all of this scholarly activity was a diverse body of venue shopping theory that remained a collection of seemingly disparate ideas. The AVS Framework attempts to bridge the gap among the various theoretical approaches that are used to understand the activities of venue choice.

The AVS Framework is a synthetic venue shopping theory that adopts Cairney's (2013) perspective that "new combinations of theories or concepts may produce new perspectives and new research agendas" (p. 1). Like many of the theories described below, a fundamental assumption of the AVS Framework is that boundedly rational individuals and groups make decisions about pursuing their policy goals in multiple decision-making venues. The AVS Framework places its primary emphasis on the institutional context as a critical factor that shapes the decision calculus of these boundedly rational groups as they are choosing venues. This institutional context involves a) a group's level of political, technical, or legal resources for approaching certain venues, b) whether a group's opponent possesses superior resources and dominates in certain venues, and c) whether venues are receptive to the group's preferred framing of the issue or conflict (see Ley and Weber 2015). To the AVS Framework institutional context matters a great deal, but this institutional milieu tells only part of the story because another fundamental 
assumption of this theory is that boundedly rational groups are capable of adaptive learning during the course of long-term policy processes (Sabatier and JenkinsSmith 1999). If groups are capable of adapting their strategies on the basis of what they have learned, then past failures or initial venue choices do not always predict future success. In fact, past failures or "bad" choices may sow the seeds for future success in that groups may learn new strategies, develop greater technical/scientific expertise, or bolster political resources that can be used in future policy battles.

The AVS Framework that is described above owes its creation to a number of scholars working in diverse theoretical traditions. Sabatier and Jenkins-Smith (1999) formulated a rational choice explanation of venue choice grounded in bounded rationality and argued that groups seeking policy change in multiple venues select those venues producing the most or best policies at the least cost. Lubell and colleagues (2010) accepted many of these same assumptions in their Ecology of Games approach but place primary emphasis on the significance of multiple policymaking venues available to boundedly rational political actors. They found that actors who are involved in these policy games come to prefer certain venues, but also shift or adapt to alternative venues when new opportunities for success arise. Sarah Pralle (2003) found similar evidence that groups develop preferences for certain venues, but argued that these preferences cause some groups to miss opportunities in other venues. Her most important insight is how structural barriers, such as standing to sue in court or rules about agency decisionmaking, make some venues unavailable to groups altogether. Finally, no discussion of venue choice is complete without a hat tip to Baumgartner and Jones (1993), who 
argued that groups manipulate how issues are framed so that their most preferred policy venue, the one that gives them the best chance of advancing their policy goals, become susceptible and sympathetic to the group's position.

The key theoretical insight advanced by the AVS Framework is that newly formed groups are found to be guided into certain venues on the basis of "easy choices" (see Table 1). The best choices occur in venues where groups possess more political, technical, or legal resources than their opponents. Groups also gravitate toward those venues that are most receptive to the group's framing of the issue, or to venues where their opponents do not yet dominate.

\section{Table 1 About Here}

"Easy worst choices" constitute venues where opponents possess more resources than the group choosing venues. Groups are also likely to avoid venues when their opponents dominate them or a group's framing of the issue does not align with the authoritative decision-makers who control the venue. Of course, the strategic choices groups make when they are choosing venues are not always easy, but the AVS Framework serves as both a theoretical framework to understand group decision-making and a practical blueprint for guiding group decisions.

\section{Research Methodology}

This paper employs a case study of the agricultural practice of field burning in Oregon's Willamette Valley to empirically test the AVS Framework for the first time, to examine the dynamics of policy entrenchment, and to explore how tough cases of policy entrenchment are reversed. Case study methods are employed when investigators are seeking to explain how and why actors behave as they do (Yin 
2009). Single case studies, especially if they take on the form of "unique" cases, have been found to advance and test past theoretical insights in powerful ways (Yin 2009). The analysis embodied in this case is unique because prior studies have focused on the venue shopping activities of groups pursuing better public health outcomes, environmental goals, or, more broadly, the provision of public goods. Here the analysis focuses on the type of groups that scholars of venue shopping have long neglected; namely, industry groups that hold different motivations for the pursuit of their goals. Motivated by the pursuit of members' private economic goals, it can be argued that the venue shopping activities of these groups may differ from groups that pursue public goods because they are seeking protection from the state, not through the state. It can, therefore, be argued that this single case meets the definition of what Yin (2009) calls a "unique" case, which can potentially establish more confidence in the external validity of research findings reported from past tests of the AVS Framework, while also fulfilling the well-established scholarly practice of observing policy change over a time period spanning multiple years (Weible 2007).

This case study required traveling throughout Oregon to interview the various stakeholders who were involved in the practice of ending and defending the practice of burning agricultural fields of crop residue. A snowball sampling method was used to contact individuals for semi-structured personal interviews that lasted between 30-120 minutes. Twelve activists, lawyers, public health professionals, medical doctors, grass seed lobbyists, and state legislators agreed to speak about a) how they selected venues to pursue their policy goals or b) how the status quo was 
defended against insurgent groups seeking to disrupt the policy status quo. By employing a snowball sampling method, it became possible to meet people who worked behind the scenes and who chose not to publicly participate in the policy conflict. These interviews were supplemented with primary and secondary source documents from newspaper archives and the State Archives in Salem, Oregon where historical documents related to agricultural field burning and the legislative and administrative policy responses to it were collected and examined. The section below explains why agricultural field burning was a problem, how policymakers first approached the problem, followed by an in-depth case study of how groups struggled to resolve the conflict.

\section{Agricultural Field Burning in Oregon}

Oregon is home to the most successful grass seed farmers in the United States, who produce nearly two-thirds of all U.S. grass seed varieties (Tippens 1989). Growers claimed that burning leftover crop residue made their success possible because it killed fungus, weeds, and other pests that affected the growth process. The amount of acreage burned every year varied, but farmers in Oregon burned up to 235,000 acres of crop residue per year. While growers benefited from field burning, the residents of Oregon's Willamette Valley, which includes the urban area of Eugene, Oregon, internalized the diffuse costs of smoke. During the 1960s, the grass smoke began mixing with other types of pollution and the air quality became so bad that one journalist wrote: 
already present, and then remains suspended. The smoke-fog combination forms a thick blanket over the Willamette Valley - carrying, then dropping, particles of black ash (Schaink 1964).

The stark visual reality of the deteriorating air quality conditions in proximity to such large population centers, coupled with growing recognition that pollution has harmful health effects, made field burning the proverbial "low-hanging" fruit for Eugene legislators seeking to regulate point-source pollution.

The various actors involved early in Oregon's field burning conflict included the Eugene City Council, whose members argued that the poor air quality caused by grass smoke was a nuisance and, worse, a menace to public health. Although active in the early stages of the conflict, the City Council was displaced by the Sierra Club, state legislators, and public health organizations, such as the Oregon Medical Association, American Lung Association, and a group called Western Environmental Law Center, who all pooled their resources together to end field burning in Oregon's Willamette Valley in 2009.

Farmers, for their part, responded to the growing opposition toward field burning in the mid-1970s by forming the Oregon Seed Council, a grass seed trade association funded through per-acre burning fees, that represented grass growers before the legislature and argued that the economic costs of regulation outweighed its public health benefits. Funding the organization through per-acre burning fees gave the Oregon Seed Council's executive director a powerful incentive to protect as many acres as possible from regulation because fewer acres eligible for burning meant a smaller pot of potential organizational revenue. Other agricultural groups, such as the Cattleman's Association and the Oregon Farm Bureau, supported the 
Oregon Seed Council's overall strategy of representing farmers before Oregon policymakers. Together, they sought to keep agencies from regulating the practice, and even took legal action in the 1980s to dismantle efforts by Oregon citizens to end field burning through a ballot measure campaign, but most of their success was achieved through their primary strategy of managing the scope of field burning conflict in legislative committees and not in other venues.

\section{Venue Shopping, Vested Interests, and Disrupting the Forces of Resilience.}

The case study of field burning politics in Oregon is separated into three sections that respectively correspond to this study's contribution to venue choice scholarship, the dynamics of policy entrenchment, and insights about the tactics of groups that seek to reverse the status quo. Section A tests the AVS Framework by demonstrating how the Oregon Seed Council made its initial venue choices and achieved policy success in doing so. Section B follows by demonstrating how the Oregon Seed Council successfully insulated its policy victory from reversal by instituting a long-term legislative strategy that allowed it to block legislation from being acted upon. Finally, Section C demonstrates how newly emerged environmental groups and their allies were able to overcome the dominance of the industry group by threatening to shift policymaking into new venues.

\section{A. The Oregon Seed Council's Adaptive Venue Shopping}

Efforts to address Oregon field burning began when the City of Eugene

created an air pollution control agency in 1957 and alerted state authorities that air 
quality in the Willamette Valley airshed was growing worse. In light of these concerns, officials from the state's environmental agency, then called the State Sanitary Authority (SSA), considered bringing the issue before Oregon's State Legislature, but one official worried, "There are several sacred cows in the state Legislature... Agriculture is one: it enjoys statutory exception" (Schainck 1964, p.1). When the Oregon legislature in 1966 considered a bill requiring growers to seek permits before igniting their fields, it confirmed that agriculture was the third rail of Oregon politics when the bill died due to opposition from the Oregon Farm Bureau and State Senator Walter Leth (R-Salem), who was a grass seed farmer (Forrester 1966).

After Tom McCall (R-OR) was elected governor, however, it became evident that growers could no longer depend on their loosely coordinated way of protecting their interests before the legislature. Prior to becoming governor, McCall was a journalist and became famous for producing a television documentary that exposed deteriorating water quality in the Willamette River (Robbins 2002). After his election, McCall made environmental cleanup his highest priority and appeared before a Senate Committee to announce that,

[The Legislature] has the opportunity of going down in history as the one that did more to promote high air and water quality standards than all the preceding legislatures in the annals of Oregon state government (Abell 1967, p.1).

During the 1969 legislative session, McCall submitted a bill to the legislature that gave the renamed SSA, now called the Department of Environmental Quality (DEQ), 
authority to regulate field burning (Lynch 1969; N.A. 1969a), a bill that

overwhelmingly passed (N.A. 1969b). ${ }^{1}$

Although the agency was designed to protect public health and the environment, the DEQ's authority to regulate field burning proved insufficient for improving air quality in the Willamette Valley. During the summer of 1969 air quality became so poor that Governor McCall declared an emergency ban on field burning and promised to end future air emergencies:

Residents of the Willamette Valley are being subjected to air pollution caused by agricultural field burning that is completely intolerable...I have checked with the Department of Environmental Quality Director...and I know every possible action under existing laws is being taken to cope with what in recent days has become an emergency...It is ridiculous that while we are phasing out wigwam burners and other polluting industrial practices we allow ourselves to be subjected to this air pollution which shocks our sensibilities and is a threat to health and safety. A complete ban on agricultural field burning is a must (N.A. 1969c, p.1).

During the next legislative session, McCall instructed Oregon Senate leaders to pass legislation banning the practice of field burning (Willis 1971a; N.A. 1971). In response, seed growers formed the Oregon Seed Council to mobilize farmers (Willis 1971b), but their efforts came too late to overcome the combination of Governor McCall's desire to cement his environmental legacy and the City of Eugene's decades-long effort to end the practice of field burning. The chief sponsor of the bill, Rep. LeRoy Owens (D-Eugene), described it as,

...a means to put the responsibility of polluting on the polluters... The important thing is that the philosophy of polluters paying for the right to pollute is inherent in this bill (Willis 1971b).

${ }^{1}$ This legislation also gave the DEQ authority to issue permits that could be distributed by local fire districts for the burning of crop residue. In 1991, this program became the Oregon Department of Agriculture's (ODA) Smoke Management Program, a program that required growers to register acres and secure permits prior to burning on days when ODA announced that weather conditions were suitable for adequate smoke dispersion. For more information about this program, see: http://arcweb.sos.state.or.us/pages/rules/oars_600/oar_603/603_077.html (last acccessed 02/17/2016) 
During the bill's hearings, Eugene's City Manager, Hugh McKinley testified that “[w]e have no ill will towards the grass seed industry...but we are concerned about clean air" (Willis 1971b), and the legislature agreed, passing a bill that eliminated field burning by 1975 (Willis 1971c; Eugene Register-Guard 1971; Willis 1971d).

The looming 1975 deadline meant that growers had the benefit of time to mobilize in opposition to the new legislative framework and they did so through the Oregon Seed Council which, due to its funding source of per-acre burning fees, was motivated by a strong incentive for its leaders to scale back legislation that limited the number of acres growers could burn. Protecting the grass seed industry meant that the organization's leaders needed to choose where to pursue its policy goals and their choices demonstrate that they were guided into venues on the basis of their resources, their opponents' resources, and their degree of access to the venues that were available in Oregon's political system. After experiencing a defeat at the hands of the legislative branch, it only seemed logical for the Oregon Seed Council to look elsewhere for the pursuit of its policy goals and so perhaps either agencies or courts provided the next best option for policy change. Growers knew that, even though the DEQ was responsible for overseeing implementation of the legislative phase-out, and their opponents had not yet cultivated strong relationships with the revamped agency, it was a relatively easy decision not to try convincing a public health agency that the implementation of the ban was too economically burdensome for the industry. With respect to the courts, growers lacked a convincing legal argument to persuade state judges, or any court for that matter, that the legislature had acted contrary to its constitutional authority to exercise police powers in 
support of public health. Even if their opponents had no clear-cut advantage in the legal arena, the choice to avoid a judicial strategy was also relatively easy because the lack of a legal argument meant that growers had insufficient legal resources, no accessibility, and no way of effectively manipulating the legal framing of the conflict in ways that could convince state and federal courts to overturn the ban (see Table 2).

Three critical developments made the legislature the easiest and best option for growers to reverse the burn ban even though the group initially suffered defeat before the legislature. First, as the ban grew nearer, so did the end of Tom McCall's second term as Oregon's governor, which ended in 1975 when Democratic Governor Robert Straub, a moderate on environmental issues, replaced him. Second, the Eugene City Council shifted its attention to other political issues, allowing growers to develop a legislative strategy without interference from their adversaries. With no single-issue group in existence to monitor the legislature's activities, the legislative venue became increasingly accessible to growers due to Eugene's attention to other matters. Finally, growers capitalized on the City of Eugene's abandonment of the legislature by hiring an experienced lobbyist named Dave Nelson to lead the Oregon Seed Council. One legislator described Nelson as, ...the best lobbyist they could get. [He] was their paid person. But they hired the best they could get for lobbying and poured money into it. Their argument, of course, was if field burning dies, we die. And we just can't go there. We can't live with it [a ban] (Personal Interview, Former State Legislator).

Growers learned from past failures that success required developing the political support and resources necessary in the legislature for weakening state legislation aimed at phasing out the practice of field burning. Once hired, Nelson wasted no 
time overseeing a large-scale lobbying campaign to convince state legislators that regulating field burning was harmful to the grass seed industry. He also formed a political action committee that was designed to elect legislators who were sympathetic to the industry. This, in effect, allowed growers to develop stronger resources in the legislature relative to opponents of field burning whose resources diminished when they shifted their attention elsewhere (see Table 2). The strategy began paying off. One industry advocate remembered that "the legislature was fairly friendly" as a consequence of the Oregon Seed Council's efforts "to get ... legislators elected who were more favorable to agriculture and to the grass seed industry" (Personal Interview, Agricultural Stakeholder).

Table 2 Here

The legislature also became more receptive, and open, to an economic framing of the field burning conflict than it had been in the past (see Table 2). This was due, in part, to the Oregon Seed Council's efforts to educate legislators about the impact of a ban on the growing community. The Oregon Seed Council arranged for farmers to meet with legislators in Oregon's capital city of Salem so that the battle over field burning regulations was reinforced as an economic issue that affected growers' bottom line:

... we had a cadre of about ten or fifteen farmers, maybe twenty, who would come up every day during the legislative session and we would lobby the senate and the house and everybody had their contacts they were assigned to. That morning we would give out their assignments and then we had their talking points, their...firsthand understandings of the impact [of a burning ban] on their farm (Personal Interview, Agricultural Stakeholder). 
It also became clearer that the legislature was receptive to the economic framing of the issue that was being advanced by growers mobilized by the Oregon Seed Council. One advocate of the seed industry remembered:

At that time, business impacts were much more important than some of them were today. [Today] they say to hell with the profitability. Profit's a bad word, we're gonna [regulate] anyway. Then [in 1975] there was a greater sensitivity to economic impact and the seed industry...We'd work the legislature; we could generally beat Eugene in the Oregon legislature. (Personal Interview, Agricultural Stakeholder).

As the 1975 deadline neared, growers learned that their efforts of "working" the legislature and advancing an economic framing of the field burning conflict could be combined with a strategy to convince state legislators that it was only a matter of time before engineers developed a mobile field burning device that minimized smoke emissions by burning crop residue at high temperatures (Harvey 1975). The technical solution of a mobile field burning device, perennially on the cusp of an engineering breakthrough, became a rather convenient justification for legislators to wait until future legislative sessions to act on the field burning issue.

The passage of time from 1971 to 1974 also meant that the ardent environmentalists who dominated the legislature and governor's office during the McCall Administration were no longer in control of the machinery of government. Newly elected Governor Bob Straub (D-OR) was sympathetic toward the Oregon Seed Council's claim that the mobile field burning device held promise and proposed an extension that allowed farmers to burn up to 235,000 acres of their fields, but to draw that amount down to 150,000 acres the following year (N.A. 1975a; N.A. 1975b; Willis 1975a, p. 1). Even though Governor Straub's plan to grant growers an extension was strongly opposed by the Sierra Club, physicians, and members of 
Eugene's City Council (Willis 1975b), the Oregon Seed Council's years-long effort to generate greater political support in the legislature culminated in a new plan that allowed growers to burn 235,000 acres in $1975,195,000$ acres in $1976,95,000$ acres in 1977, and 50,000 acres in 1978. This agreement to draw down the amount of acreage to be burned over a number of years would have the critical effect of a) keeping the field burning issue a legislative matter, and b) allowing the Oregon Seed Council to wait until the right political conditions were in place to weaken these regulations even more.

\section{B. Vested Interests, Policy Entrenchment, and Institutional Inertia}

The Oregon Seed Council wasted no time insulating its policy success from reversal after passing the legislation, raising $\$ 77,350$ to continue funding its strategy of legislative advocacy (Lynch 1976a). The Seed Council used this money to lobby for additional reversals of the ban, which, later, allowed it to generate more revenue from growers as more acreage was registered and burned. In the five years following the Oregon Legislature's ban, the Oregon Seed Council had grown into "a very well financed, powerful political organization" that came to dominate the legislature (Lynch 1976b, p. 7). One former legislator remembered that,

The grass seed growers cried and moaned and whined and put together a huge ag industry coalition and got the ban turned into a phase-down and then the phasedown turned into a 250,000 acre cap...The 1971 ban was led by Lane County and Benton County Legislators, the cities of Corvallis and Eugene, but it was something that was dealt with in 1971 as a pollution control measure. It surprised the hell out of the farmers and they of course ramped up and turned right around and the ban became a quarter of a million acres (Personal Interview, Former State Legislature).

The Oregon Seed Council continued its momentum and in the next legislative session sought permission to burn the original 235,000 acres (Smith 1977). Even though this proposal was altered to give growers permission to burn 190,000 acres 
that year (nearly 100,000 acres more than the 95,000 acres that the 1975 legislation allotted), the legislature's passage of it clearly demonstrated how effective the Oregon Seed Council became at executing its strategy of weakening field burning regulations.

When seed industry advocate Vic Atiyeh (R-OR) became Oregon's newly elected Governor in 1978, all of the political conditions were in place for the Oregon Seed Council to try eliminating all limits on field burning (Smith 1979). The legislature agreed and opponents of field burning had nowhere to turn but the courts, but even that strategy fell short of reversing the Oregon Seed Council's policy achievements (N.A. 1979). With administrative agencies lacking power to regulate the practice of field burning, the Oregon Seed Council protected its policy victories from reversal by continuing to execute a legislative strategy, thus generating the institutional inertia and policy stability that frustrated opponents of field burning.

The Oregon Seed Council's efforts to insulate its policy victories from reversal by instituting a blocking strategy was made easier by the Oregon legislature's institutional characteristics. The seed council was especially successful in exploiting the institutional rules of the legislative game in ways that kept other groups from acting on field burning legislatively. These institutional characteristics involved a multitude of veto points that allowed the Oregon Seed Council to keep legislation from being acted on and, even in the event that legislation was proposed, the House and Senate committees on agriculture always provided a reliable blocking point. A blocking strategy was made even easier by the fact that legislative business occurred in Oregon bi-annually. One lobbyist explained it this way: 
It's easier [to keep issues off the agenda], not because of the length of time, but you have a more compressed time to deal with issues. So you got basically one shot to get something up. You can't come back and back and back unless you're cutting deals at the end of the session and that's where the so-called end game takes place. As you come down to the end game, the speaker has a list of things, the majority leader has a list of things, and they go to the members and say, "If you want your community college funding you're going to vote for this field burning bill." That's where the line up really takes place (Personal Interview, Agricultural Stakeholder).

Keeping legislation from reaching the agenda could only be achieved through

sustained advocacy efforts that were made possible by the collection of mandatory

per-acre burning fees raised from grass growers. The Oregon Seed Council used

these revenue sources to bankroll lobbying and public relations activities that cost

an average of $\$ 25,000$ per year (Ley 2011). A typical year of advocating on behalf of

grass growers was described in the following way:

.... three of us were [lobbying] We started the session out by visiting...the whole ninety Oregon legislators - we may have missed one or two, but I don't think so. Then we started with an educational packet for them [the legislators], sat down for about a half-hour meeting with each and every one of them and just [tried] to update them on...the background, the history, where we were as an industry, what we're doing, and that took us probably through first of March. We spent January and February doing that background educational work. After that, there was a hearing held on a House Bill...so obviously we prepared testimony for that, the whole time encouraging farmers to come to the capitol. We were somewhat successful. We had a few farmers make multiple trips and quite a few farmers make single trips to talk with their own legislators. We worked with them, preparing them for those meetings, [we] attended some, didn't attend others...all the while throughout that, during legislative meetings [we were] talking about the issue, vote counting, trying to line up votes...down to the $11^{\text {th }}$ hour to the last day when the bill finally passed the Senate and the House. That kind of sums it up (Personal Interview, Agricultural Stakeholder).

By focusing on maintaining relationships with legislators and using the multiple veto points of a legislature that met only bi-annually, the Oregon Seed Council successfully insulated its policy achievements from reversal, created institutional inertia by supporting legislatively-prescribed burning limits versus delegating the decisions to an agency, and created a decade of policy stability until 1988. 


\section{Focusing Events, Vested Interests, and Combating the Forces of}

\section{Resilience.}

The policy status quo was disrupted when poor visibility from grass smoke caused a deadly car pileup leaving seven motorists dead and countless others demanding an explanation for the cause of the accident. Not long after the accident, Governor Neil Goldschmidt (D-OR) declared a stop to burning until the legislature decided how best to respond. One former legislator recalled,

The catalyst of course [for considering new legislation] was the 1988 accident because it was so horrendous - it happened right in the middle of the valley on interstate 5 killing children and burning children to death, causing horracious amounts of injuries to others. The whole process turned the corner (Personal Interview, Former State Legislator).

A small group of residents formed Oregonians Against Field Burning (AP 1988), a group vowing to end field burning by ballot measure if it was unsuccessful at ending it legislatively (AP 1989). In response to growing public intolerance of grass smoke, the Oregon Seed Council instituted an aggressive public relations campaign advertising the seed industry's critical role in Oregon's economy and its willingness to compromise with advocates of stricter controls (AP 1988; Detzel 1989a).

The public relations strategy did not deter Democratic State Senator Grattan Kerans (D-Eugene) from promising to eliminate field burning through legislation (Detzel 1989b). He was a political entrepreneur who gave Oregonians Against Field Burning the type of political capital that it needed to get legislation passed. He accused the grass seed industry of using "the air as an open sewer" and framed the conflict as a public health hazard that justified a ban on field burning (Mapes 1989). When the Oregon Seed Council responded with an advertising campaign claiming 
that a ban would cost $\$ 750$ million and the disappearance of 10,000 jobs, Kerans

mocked the public relations strategy by saying,

I see we're now up to $\$ 750$ million. Eventually, this industry will be responsible for all jobs, and the state of Western Civilization will hinge upon its continued [existence]...the land will stand fallow, the homes will be windowless, the varmints will be using them as their nests. The towns will collapse, the grass will grow in the streets. That's the typical response: An apocalypse that will goad even me to send voluntary contributions to their public-relations campaign. The industry in its utter arrogance needs to realize I didn't arrive at this Legislature off the back of a turnip truck this morning... The day of reckoning is coming in Oregon. I won't put out a sucker bill as an initiative for them to pound on. I won't make a hobby of this industry. I will commit every day of my life to this issue, and I pledge you, I am not going to lose this fight (Duins 1989).

Kerans's promises culminated in the drafting of numerous bills that drew hundreds of onlookers during committee hearings, including one that attracted 500 spectators (Boyd 1989).

Although the car accident provided the tragic spectacle needed to overcome the legislative inertia that opponents of field burning experienced in Oregon, the long-term legislative strategy implemented by the Oregon Seed Council and its decades-long experience blocking attempts to regulate the practice were too much for the coalition trying to stop field burning. Concerned that legislation went "too far too fast," (Detzel 1989c, 1989d), the Oregon Seed Council drew upon its institutional knowledge of the legislative game to block a bill that restricted acres burned from 250,000 acres to 150,000 acres (N.A. 1989). After watching the bill die in the House, and knowing that its resources were no match for the legislative resources possessed by growers, Oregonians Against Field Burning spent $\$ 10,000$ collecting 15,000 petitions and launched a short-lived ballot initiative campaign that was defeated when the Oregon Seed Council petitioned the Oregon Supreme Court to change the wording of the ballot measure's title (USA Today 1989). The timing of 
the lawsuit left Oregonians Against Field Burning with very little time to finish collecting signatures under the ballot measure's rewritten title (Detzel 1989c;

Mapes 1990). One seed industry advocate explained the strategy behind changing the wording of the ballot measure:

Yeah, we said if we can get this [the ballot measure title] changed - one word is all we need - and that's gonna set them back and really compress their period of time that they have to get the signatures. At the time what we were doing was politics, technical and legal. You have to be as smart as the enemy or smarter than the enemy in all three of those areas (Personal Interview, Agricultural Stakeholder).

Even though the Oregon Seed Council succeeded in keeping the issue of field burning from being addressed through the ballot initiative process, there still remained concerns from members of the organization about the ease with which Oregonians Against Field Burning collected 15,000 signatures to place the issue on the November ballot.

When Republicans seized control of the State House that November growers saw the arrival of Republican leadership as an opportunity to negotiate a new legislative framework they could live under (Walth 1991). One industry lobbyist explained how growers came to this conclusion:

Coming forward from the '88 accident, the fight went out of the farmers....[W]e can't raise enough money to fend [regulation] off now because all you have to do is show pictures of the wreck and its over... It gave us a lot more bargaining power to come up with something we could survive [when Republicans took control of the Legislature in 1991]. We knew that there was going to be very restrictive legislation and so get your best deal and recognize that's the times you're living in (Personal Interview, Agricultural Stakeholder).

Despite its success avoiding the ballot initiative challenge, the high financial cost of successfully waging another campaign weighed heavily on the minds of the Oregon Seed Council's members. According to one member,

We polled it [support for growers facing a ballot initiative campaign], and we had polled it several times. We polled it back in the '70s, we polled it in the '90s, and 
basically we had 75 percent support for the industry. What we weren't sure of was could we fund the campaign?...[W]e were predicting [a ballot initiative campaign would cost] somewhere between $\$ 1$ million and $\$ 1.5$ million to really put on a winning campaign. That's a lot to raise (Personal Interview, Agricultural Stakeholder).

Uncertain about its prospects of funding and winning a ballot measure campaign, the Oregon Seed Council adopted the same legislative strategy that had worked so well for it in the past. This time, the Oregon Seed Council came out in support of an incremental, seven-year field burning drawdown that allowed growers to burn 65,000 acres by 1998 , which was still more than the 50,000 acres that were allotted for 1978 under the previous legislation, in return for shifting regulatory oversight from the DEQ to the Oregon Department of Agriculture (Hill 1991). One Oregon legislator described the circumstances leading to the legislation in this way:

The farmers were pushed back, that didn't mean they couldn't win because they survived the 1989 session by making sure there was no compromise bill and we couldn't negotiate but we got their attention in 1989 and 90 with our initiatives and they knew the game was up when the ' 91 session began. And we got a better bill. We got a lot better bill in ' 91 than what we were willing to do in ' 89 . And that came as a result of the political pressure of collecting...75,000 to 80,000 [sic] signatures on two different petitions and you put those two campaigns together around one [petition] and you keep this thing in the press for two years, [and growers] knew they were cooked. As I told them [the seed industry], do it with me now or do it on Election Day (Personal Interview, Former State Legislator).

While the passage of legislation lowered the number of acres farmers could burn annually, and lowered the amount of acreage the organization could use for collecting burning fees from its members, the regulatory framework nevertheless gave growers another twenty years to continue burning under the oversight of a sympathetic clientele agency.

Even though growers were burning less under this new legislative framework, the Willamette Valley remained a hotbed for poor air quality during the late summer days of August. Over the next decade, growers defended themselves 
against public health professionals who communicated the negative public health effect of small particulate matter to Oregon policymakers. It was only a matter of time until field burning was thrust back on to the legislative agenda when Democrats seized control of the Legislature and Governor's office during the national Democratic wave of 2006. The Oregon Seed Council quickly launched a large-scale campaign in response to this shift in legislative control, causing one state legislator, Rep. Paul Holvey (D-Eugene), to promise, "It seems to be the issue being lobbied the hardest around here in the first few days...They [the Oregon Seed Council] have money to spend...The people who complain about their practice, the public, they don't have lobbyists. And I'm here to represent them" (Lies 2007a).

With opposition to field burning rising, and a legislature narrowly controlled by Democrats sympathetic to the public health and environmental framing of action on field burning, the Oregon Seed Council doubled-down on its legislative strategy and hired Larry Campbell, a former speaker of the Oregon House who helped negotiate the field burning legislation that passed in 1991, to represent the seed industry alongside Dave Nelson (Steves 2007a). The Oregon Seed Council's hiring was followed by Rep. Paul Holvey's announcement that he was introducing legislation banning field burning and vesting regulatory oversight for its phase-out in the DEQ (Sinks 2007; Steves 2007b). The bill's hearings in the House Committee on Health Care drew 120 onlookers who watched supporters of the grass seed industry use empirical data to challenge claims that field burning caused respiratory problems (Dietz 2007a; Lies 2007b). The Oregon Seed Council's Dave Nelson testified, 
DEQ's emissions inventory shows that field burning contributes $2 \%$ or less to the total particulate load in the Willamette Valley during the summer, and $1 \%$ or less during the year...The largest sources of particulate are residential wood heating/fireplaces ( $42 \%$ winter period) and fugitive dust year around. DEQ air quality administrators state that the Willamette Valley Smoke Management program is a "model" for other states (underline original; Nelson and Campbell 2007).

In response, groups like the American Lung Association and the Oregon Medical Association drew support from academic studies demonstrating the negative public health impact of small particulate matter. One representative of the American Lung Association, testified,

More than 2,000 peer-reviewed studies on the subject have been published since 1996, confirming the strong relationship between particle pollution, illness, hospitalization and premature death. The U.S. Environmental Protection Agency recently completed a review of these studies and linked particle pollution to premature death from cardiovascular disease, heart attacks and strokes, as well as worsening asthma, [Chronic Obstructive Pulmonary Disease] COPD, and may cause lung cancer (Kaye 2007).

After passing the House Committee on Health Care (Dietz 2007b), the bill was sent to the House Agriculture Committee where, even though it was controlled by Democrats, the bill faced resistance and died after fifty grass growers and agricultural companies like J.R. Simplot and Scotts Co. testified against it (Dietz 2007c).

The bill's failure in committee did not deter public health advocates from mobilizing resources to prepare for a ban the next legislative session. They grew their coalition to include Eugene's Western Environmental Law Center, an organization that threatened litigation if the legislature continued its history of failing to act. Growers unwittingly gave this coalition ammunition when they agreed to suspend burning during the 2008 Olympic Track and Field Trials being held in Eugene (Esteve 2008). The public health community interpreted the seed industry's self-imposed moratorium as tacit admission that field burning was dangerous to 
public health, causing Democratic Governor Ted Kulongoski to publicly support banning the practice during the 2009 session (N.A. 2008; Dietz 2008). When legislative Democrats gained an even larger majority in the 2008 elections all of the pieces were in place for the elimination of field burning.

By 2009, Rep. Paul Holvey had had enough. It became his mission to overcome past obstacles and to pass a bill that strongly curtailed burning in Oregon's Willamette Valley. By then, the Oregon Seed Council's legislative game of blocking legislation in committee had become all too familiar with him. Concerned that any House bill would be subsequently referred to, and killed, in the House Agricultural Committee, he asked Eugene State Senator Floyd Prozanski to cosponsor a bill on the Senate side where it cleared the Senate Environment and Natural Resources Committee and was referred to the Joint Ways and Means Committee (Personal Interview, State Legislator). ${ }^{2}$ The Oregon Seed Council spent what was remaining of the legislative session seeking to block action from being taken there, but Eugene legislators knew that the organization would try bleeding out the clock. That explains why the Eugene delegation drafted a bill allowing Oregon voters to eliminate field burning through a ballot measure, which, according to one legislator,

...was meant to be a shot across the bow to say, "Look, if you guys will not talk to us and if you guys will not work with us to try to protect our communities from the impacts of your practices we're gonna take this to the ballot and run a campaign that you will have to defend and we are gonna use the media and the medical community

\footnotetext{
2 Accordingly, the Oregon legislature requires that when legislation has a "fiscal impact" then it must be referred to the Joint House and Senate Ways and Means Committee after it is approved through a policy committee. This allowed the bill to circumvent the House Agriculture Committee. Because the bill had a "little bit of a fiscal impact" it went to this committee where there was "a better committee make-up" rather than the House Agricultural Committee (Personal Interview, State Legislator).
} 
and potentially shut down your whole industry from burning across the state"

(Personal Interview, State Legislator).

After the referendum proposal was announced, the joint committee quickly acted on the original bill phasing out field burning in the Willamette Valley, which narrowly passed both the House, the Senate, and was signed into law by the Governor (Lies 2009a, 2009b).

In summary, a state legislator, along with a highly mobilized public health community, overcame decades of grass seed industry dominance by beating the Oregon Seed Council at its own game of legislative politics, but the magnitude of political change required to dislodge the hard fought victories of the grass seed industry makes this a remarkable and unique case of policy retrenchment. Larger Democratic majorities in both the Oregon House and Senate were needed to make the legislature accessible to this public health coalition. As clear evidence became available about the public health hazards of small particulate matter, the public health framing of the conflict could no longer be ignored and gained greater acceptance in comparison to the Oregon Seed Council's economic framing of field burning. This combination of accessibility, a legislative policy entrepreneur with special insight about the rules of the legislative game, and a venue that was increasingly susceptible to a public health frame allowed the coalition to succeed in convincing lawmakers to ban field burning in Oregon's Willamette Valley.

\section{Discussion}

Groups seeking policy change encounter choices to make about which venue gives them the best chance of achieving their policy goals. How do they make these 
choices? Previous research advances a theory of "easy choices" (Ley and Weber 2015). While not all choices are easy, choices typically fall somewhere between the theoretical extremes of an "easy best choice" and an "easy worst choice." This case study finds empirical support that, as an emergent group, the Oregon Seed Council was guided into venues on the basis of its relative resource strengths, its support from a newly elected governor sympathetic to the growing community, and the increasingly accessible nature of the legislature that supported the economic framing advanced by growers. Although these findings support the AVS Framework, the case study does not demonstrate that venue shopping always entails trial-and-error learning about which venues do and do not offer the best opportunities for success. Instead, groups may achieve success in the first venue they choose and stick with the strategy. This became especially evident when the Oregon Seed Council avoided overturning the burn ban in agencies and courts but, instead, opted to seek its reversal through the same legislative process that produced it.

In addition to finding empirical support for the AVS Framework, this case study also demonstrates how vested interests insulate their policy victories from reversal. There is no question that institutional reformers face strong resistance from vested interests who benefit from the policy status quo, but what is seen when we look closer at how these interests come to power and maintain their dominance? Scholars have long known that "vested interests" arise from the unintended consequences of policies "that reconfigure arrangements of power in society" (Mettler and SoRelle 2014, p. 152). The Oregon Seed Council's rise to dominance 
should be a cautionary tale for environmental policymakers because this powerful organization's origins can be found in the same statutes that were designed to regulate the industry. This case study demonstrates how, in response to the Eugene City Council's legislative achievement and abandonment of it, growers mobilized to represent their interests before the legislature, hired a lobbyist by collecting peracre burning fees to execute a year-round legislative strategy, shaped a hostile statute so that it contained virtually no limits on field burning by 1979 , and, consequently, dominated this area of agricultural and environmental policy in Oregon for the next thirty years. While the scholarship surrounding "vested interests" is dominated by research examining their origins in distributional policymaking environments, this case study demonstrates how vested interests arise in response to regulatory programs and can succeed and maintain their organizations if their incentives to overturn or weaken policy are aligned with their funding structure. The Oregon Seed Council's incentives to protect more acreage through legislative negotiation were directly aligned with the organization's funding structure that came from per-acre burning fees, an incentive structure that is uncommon in organizations seeking the provision of public goods, such as public health. The fact that the Oregon Seed Council so jealously guarded the acreage under its protection so that it could protect its source of organizational funding might explain how vested interests come to be so effective in developing long-term strategies that cause long periods of policy stability. Another important lesson that can be drawn from this case involves the critical interplay of framing, institutions, and macropolitical forces that combine to 
shape policymaking processes in ways that allow the forces of resilience to become so adept at protecting the status quo. Robert Duffy's (1997) insights surrounding the nuclear power industry remind us that conflicts over environmental problems like field burning can potentially take on a number of different competing frames that are contingent on broader macropolitical forces. It was during the environmental decade of the 1960s, for instance, that the City of Eugene succeeded in passing legislation by framing the byproducts of field burning as a nuisance and public health hazard. As the broader political environment of the 1960s gave way to the 1970s, however, a whole new set of values that emphasized economic freedom and new limits on government regulation of property began taking hold in the American West (Rosenbaum 2014), becoming manifest in movements like the Sagebrush Rebellion, the property tax revolts of California, and the election of Western Governors like Gov. Vic Atiyeh (R-OR), who became a powerful symbol of these values in Oregon politics. It can be argued that Oregon's state legislature, composed of part-time citizen legislators who met only bi-annually, was particularly susceptible to the Oregon Seed Council's economic framing of the issue, and the leadership of a full-time Governor who represented the dominant values that were sweeping across the American West at the time. Just as the broader political conditions of the 1960s gave way to the 1970s, the late 1980s and early 1990 s emphasized environmental values sensitive to concerns about public health (Rosenbaum 2014). As these environmental values became dominant, legislative revisions to Oregon field burning policy were increasingly likely when the highly visible focusing event, the accident of 1988, thrust field burning back on to the 
political agenda. However, the case of field burning in Oregon demonstrates that institutions and the forces of resilience that make them resistant to change are powerful even in light of changing values and acute shocks to the political system. The fact that the Oregon Seed Council was so effective in fending off immediate change in the aftermath of the tragic car pile-up demonstrates the power of knowing how to manipulate the institutional rules of the game to keep policy from being acted upon and to produce institutional inertia.

There are, furthermore, practical lessons that may be drawn from this study of environmental policymaking in Oregon. Insulating policy victories from future reversal is a common strategy for established groups facing opponents who can challenge the policy status quo through multiple decision-making venues. This case study not only demonstrates the rise to power of agricultural interests, but also their fall from grace. One practical insight that can be drawn from this study of Oregon field burning is that even though political actors, such as the Oregon Seed Council, may come to dominance, they can be challenged when newly emerged groups partner with policy entrepreneurs who are skillful at exploiting windows of opportunity (Kingdon 1995). That may explain why the best examples of legislative policy change, the 1991 and 2009 drawdowns, occurred when state legislative policy entrepreneurs challenged the seed industry by successfully manipulating the media to keep policy windows open long enough to pass legislation and to threaten the expansion of the policy conflict into other venues, such as the ballot initiative process $(1989,2009)$ and the courts (2009). This provides empirical support not only for the ecology of policy games insight that policies made in one venue cause 
spillover externalities and shape policy in other venues (Lubell 2013), but that the threat or prospect of policy being made in one venue can affect policymaking in other venues.

\section{Conclusion}

The case study of Oregon field burning clearly demonstrates the successful efforts of the Oregon Seed Council to fend off policy change over a fifty year period, from 1960 until 2010. This group achieved success by instituting a legislative lobbying campaign that allowed it to institute a long-term blocking strategy. When policy change became imminent, the Oregon Seed Council acceded to the demands of groups seeking policy change, but did so on their own familiar turf in the legislature. They allowed gradual drawdowns of burning, knowing that a) new technology might emerge to eliminate the need to burn grass fields, or b) political fortunes may change and allow for a later reversal of legislation.

This study finds support for the for the AVS Framework's theory of "easy choices" and makes additional contributions to policy scholarship by illustrating the ways in which vested interests are able to insulate their policy victories from reversal by instituting long-term strategies that cause long periods of institutional inertia and, thus, policy stability. Even though this study demonstrates the success of industry groups that seek to achieve long-lasting policy stability, there is good news for groups that are seeking to challenge them because this study also demonstrates very clearly how emergent or disadvantaged groups can use their legislative allies and the threat of policymaking in other institutional venues to level the political playing field against their stronger opponents. 


\section{References}

Abell, Ron. 1967. “Tough Pollution Steps Urged," Eugene Register-Guard, 15 Mar 1967, Sec. A.

A.P. 1988. "Experts Call Field Smoke Health Risk," Spokesman Review, 5 Sep 1988, Sec. A.

. 1989. "Burning Ban Backers Seek Vote on Issue," Eugene Register-Guard, 7 Mar 1989, Sec. A.

Baumgartner, Frank R., and Bryan D. Jones. 1993. Agendas and Instability in American Politics. Chicago: The University of Chicago Press.

Boyd, Jim. 1989. "Seed Farmers Not Rooting for Burn Ban," Eugene Register-Guard, 14 Apr 1989, Sec. A.

Buffardi, Anne L., Robert J. Pekkanen, and Steven Rathgeb Smith. 2015. "Shopping or Specialization? Venue Targeting among Nonprofits Engaged in Advocacy." Policy Studies Journal. Online First.

Cairney, Paul. 2013. "Standing on the Shoulders of Giants: How do we Combine the Insights of Multiple Theories in Public Policy Studies?" Policy Studies Journal 41: $1-21$.

Detzel, Tom. 1989a. "State Called Morally Responsible for Crash," Eugene RegisterGuard, 12 Jan 1989, Sec. A.

. 1989b. "Outlook Hazy for Legislation to Ban Field Burning," Eugene RegisterGuard, 28 Jan 1989, Sec. A.

. 1989c. "Unaffected to Decide Field Burn Bill," Eugene Register-Guard, 12 Jun 1989, Sec. A.

. 1989d. "Field Burn Bill Faces Fight on House Floor," Eugene Register-Guard, 16 Jun 1989, Sec. A.

Dietz, Diane. 2007a. "Burn Ban, Rekindled," The Register-Guard, 8 April 2007, Sec. A. 2007b. "Health Panel OKs Field Burning Ban," Eugene Register-Guard, 14 Apr 2007, Sec. D. 2007c. "House Panel Lets Field Burn Ban Die," The Eugene Register-Guard, 1 May 2007, Sec. A.

. 2008. "Seed Farmers Face New Rivals," The Eugene Register-Guard, 11 July 2008, Sec. A.

Duffy, Robert J. 1997. Nuclear Politics in America: A History and Theory of Government Regulation. Lawrence, KS: University Press of Kansas.

Duins, Steve. 1989. "Kerans Meets Field Fires with Fire," The Oregonian, 16 April 1989, Sec. E.

Esteve, Harry. 2008. "Field Burning Issue Aflame," The Oregonian, 21 Jun 2008, Sec. A.

Eugene Register-Guard, The..1971. "New Law Should Cool Burning Issue," Eugene Register-Guard, 4 Jun 1971, Sec. A. 
Forrester, Mike. 1966. “In Field Burning,” The Eugene Register-Guard, 26 Apr 1966, Sec. B.

Harvey, Jr., Paul W. 1975. "Most Favor Field Burn Extension: State Legislatures Quizzed on Issues," The Bend Bulletin, Sec. A.

Hill, Gail Kinsey. 1991. "Senate Votes to Phase Out Field Burning," The Oregonian, 11 June 1991, Sec. A.

Kaye, Dana. 2007. Testimony Before House Committee on Health Care, 6 Apr 2007, Salem, OR: Oregon State Archives.

Kingdon, John W. 1995. Agendas, Alternatives, and Public Policies, $2^{\text {nd }}$ Edition. New York: Harper Collins.

Ley, Aaron J. 2011. "How the Breathers Beat the Burners: The Role of Technical, Political, and Legal Capital in Resolving Environmental Disputes."

Dissertation. Pullman, WA: Washington State University Libraries.

Ley, Aaron J., and Edward P. Weber. 2015. "The Adaptive Venue Shopping Framework: How Emergent Groups Choose Environmental Policymaking Venues." Environmental Politics 24: 703-722.

. 2014. "Policy Change and Venue Choices: Field Burning in Idaho and Washington." Society \& Natural Resources 27: 645-655.

Lies, Mitch. 2007a. "Field Burning Defenders Launch Offensive," Capital Press, 15 Jan 2007, Sec. C. 2007b. "Field Burning Ban has Hearing: Ag Brings Figures Showing Smoke from Burning not Harmful," Capital Press, 13 April 2007. . 2009a. "Oregon Senate Passes Field Burning Ban," Capital Press, 25 Jun 2009. . 2009b. "House Sends Field Burning Scale Down to Governor's Desk," Capital Press, 29 Jun 2009.

Lubell, Mark, Adam D. Henry, and Mike McCoy. 2010. "Collaborative Institutions in an Ecology of Games," American Journal of Political Science 54 (2): 287-300.

Lubell, Mark. 2013. "Governing Institutional Complexity: The Ecology of Games Framework." Policy Studies Journal 41: 537-559.

Lynch, Bill. 1969. "Ryegrass Growers Unhappy with Proposed Burning Bills," Eugene Register-Guard, 23 Jan 1969, Sec. A.

. 1976a. "Straub Tells Seedmen Public Will Must be Accepted," Eugene RegisterGuard, 28 Jan 1976, Sec. A.

1976b. "Unity Gives Growers Big Clout," Eugene Register-Guard, 18 Mar 1976, Sec. A.

Mapes, Jeff. 1989. "Bill Aimed at Banning Oregon Field Burning," The Oregonian, 21 January 1989, Sec. E.

. 1990. "Initiative Backers Scramble to get their Petitions in before Deadline," The Oregonian, 7 July 1990, Sec. A.

Mettler, Suzanne, and Mallory SoRelle. 2014. "Policy Feedback Theory," In Theories of the Policy Process, eds. Paul A. Sabatier and Christopher M. Weible. Boulder, CO: Westview Press.

Moe, Terry M. 2015. "Vested Interests and Political Institutions." Political Science Quarterly 130: 277-318

N.A. 1969a. "Group Supports Tightened Field Burning Rules," The Bend Bulletin, 18 Feb 1969, Sec. A. 
. 1969b. "Accomplishments of 1969 Legislature Summarized," The Bend Bulletin, 24 May 1969.

. 1969c. "Seed League Protests: Valley Field Burning Brings Get-Tough Call," The Bend Bulletin, 4 Aug 1969, Sec. A.

. 1971. "Bill Hearing Slated Feb. 16," Eugene Register-Guard, 7 Feb 1971, Sec. A. 1975a. "Governor in Favor of Burn Extension," The Bend Bulletin, 31 Jan 1975, Sec. A.

. 1975b. "Field Burning Compromise Goes Easier on Seed Industry," The Bend Bulletin, 5 Feb 1975, Sec. A.

. 1979. "EPA Expected to Raise Field Burning Acreage," The Bend Bulletin, 20 Jul 1979, Sec. A.

. 1989. "Committee Approves Bill to Slash Field Burning," Eugene RegisterGuard, 12 May 1989, Sec. C.

2008. "Environmentalists aim to Stretch Burn Ban Past Olympic Trials," The Bend Bulletin, 22 June 2008.

Nelson, Dave, and Larry Campbell. 2007. Statement in Opposition to HB 3000, 30 Apr 2007, Salem, OR: Oregon State Archives.

Pralle, Sarah B. 2003. "Venue Shopping, Political Strategy, and Policy Change: The Internationalization of Canadian Forest Advocacy." Journal of Public Policy 23: 233-260.

Robbins, William G. 2002. "People, Politics, and the Environment Since 1945: Pollution in Paradise." In The Oregon History Project, ed. The Oregon Historical Society. http://www.ohs.org/education/oregonhistory/narratives/subtopic.cfm?sub topic_ID=173. Accessed 03/19/2015.

Rosenbaum, Walter A. Environmental Politics and Policy, $9^{\text {th }}$ Edition. Thousand Oaks, CA: CQ Press.

Sabatier, Paul A., and Hank Jenkins-Smith. 1999. "The Advocacy Coalition Framework: An Assessment," In Theories of the Policy Process, ed. Paul A. Sabatier. Boulder, CO: Westview Press.

Schaink, Henry. 1964. “'Time Running Out' for Field Burning," Eugene RegisterGuard, 13 Sep 1964, Sec. A.

Schattschneider, E.E. 1963. The Semi-Sovereign People: A Realist's View of Democracy in America. New York: Holt, Rinehart, and Winston.

Sinks, James. 2007. "Field Burning may be Banned," The Bend Bulletin, 14 March 2007.

Smith, Steven. 1977. “235,000-Acre Field Burning Proposal Aired," Eugene RegisterGuard, 13 Apr 1977, Sec. A.

. 1979. "Bill Ending Burn Limits Introduced: Predictably, Eugene Finds it Unacceptable," Eugene Register-Guard, 2 Feb 1979, Sec. A.

Steves, David. 2007a. "Field Burning Defenders Launch Offensive," The Eugene Register-Guard, 15 January 2007, Sec. C.

. 2007b. "Seed Field Burning Ban Moves Forward," The Eugene Register-Guard, 14 March 2007, Sec. A.

Stone, Deborah. 2001. Policy Paradox: The Art of Political Decision Making. New York: W.W. Norton \& Company. 
Tippens, Jerry. 1989. "Health, Grass Seed Must Share Valley," The Oregonian, 26 January 1989, Sec. B.

USA Today. 1989. "Albany," USA Today, 15 Jan 1990, Sec. 6A.

Walth, Brent. 1991. "House Speaker Sets Priorities for Legislative Agenda," Eugene Register-Guard, Sec. A.

Weible, Christopher M. 2007. "An Advocacy Coalition Framework Approach to Stakeholder Analysis: Understanding the Context of California Marine Protected Area Policy." Journal of Public Administration Research and Theory 17: 95-117.

Willis, Henny. 1971a. "McCall Urges 'Reverence for Life, Respect for Nature," Eugene Register-Guard, Sec. A.

. 1971b. "Eugene Officials Renew Assault on Field Burning at Hearing," Eugene Register-Guard, 17 Feb 1971, Sec. A.

1971c. "Field Burning Bill Carries both Good and Bad News for Lane," Eugene Register Guard, 17 Mar 1971, Sec. A. 1971d. "1975 Field Burning Cutoff Signed into Law by McCall," Eugene Register-Guard, 30 Jun 1971, Sec. B. 1975a. "It Sounded Like'71 All Over Again," Eugene Register-Guard, 25 Feb 1975, Sec. A. . 1975b. "Mayor, Medic, Athletes Spell Out Burning Woes," Eugene RegisterGuard, 26 Feb 1975, Sec. A.

Yin, Robert K. 2009. Case Study Research: Design and Methods, Fourth Edition. Thousand Oaks, CA: Sage Publications. 
Table 1: Easy Venue Choices

Degree of Venue Accessibility

\begin{tabular}{ccccc} 
Decision Venue & $\begin{array}{c}\text { Strength of } \\
\text { Group } \\
\text { Resources }\end{array}$ & $\begin{array}{c}\text { Opponents' } \\
\text { Resources }\end{array}$ & $\begin{array}{c}\text { Opponents' Degree } \\
\text { of Dominance }\end{array}$ & $\begin{array}{c}\text { Venue Image } \\
\text { Receptivity }\end{array}$ \\
\hline $\begin{array}{c}\text { Easy "best" } \\
\text { Choice }\end{array}$ & High & Low & Weak & High \\
$\begin{array}{c}\text { Easy "worst" } \\
\text { Choice }\end{array}$ & Low & High & Strong & Low \\
\hline
\end{tabular}

Adapted from Ley and Weber (2015). 
Table 2: Oregon Seed Council Venue Choices

Degree of Venue Accessibility

\begin{tabular}{ccccc} 
Decision Venue & $\begin{array}{c}\text { Strength of } \\
\text { Group } \\
\text { Resources }\end{array}$ & $\begin{array}{c}\text { Opponents' } \\
\text { Resources }\end{array}$ & $\begin{array}{c}\text { Opponents' Degree } \\
\text { of Dominance }\end{array}$ & $\begin{array}{c}\text { Venue Image } \\
\text { Receptivity }\end{array}$ \\
\hline Legislature & $\begin{array}{c}\text { Growing } \\
\text { (Med-High) }\end{array}$ & $\begin{array}{c}\text { Diminishing } \\
\text { (Low) }\end{array}$ & $\begin{array}{c}\text { Weak } \\
\text { (Neglected) }\end{array}$ & High \\
Agency ${ }^{3}$ & Low & Low & Weak & Low \\
Courts & Low & Low & Weak & Low \\
\hline
\end{tabular}

3 Oregon Department of Agriculture 